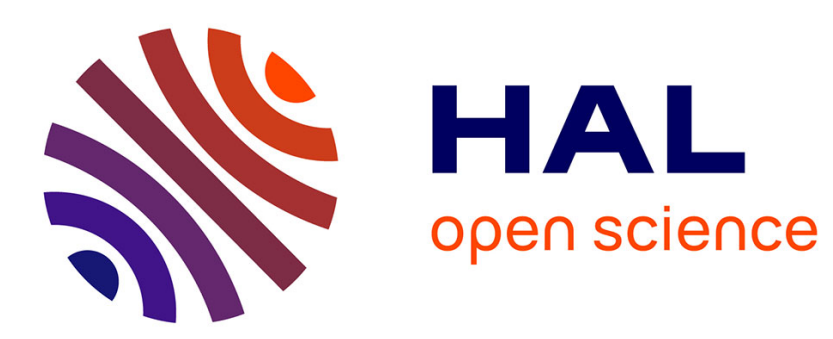

\title{
Reconstructing the globalisation of tourism: A geo-historical perspective
}

\author{
Andreea Antonescu, Mathis Stock
}

\section{To cite this version:}

Andreea Antonescu, Mathis Stock. Reconstructing the globalisation of tourism: A geo-historical perspective. Annals of Tourism Research, 2014, 45C (1), pp.77-88. 10.1016/j.annals.2013.12.001 . hal-00716824

\section{HAL Id: hal-00716824 \\ https://hal.science/hal-00716824}

Submitted on 11 Jul 2012

HAL is a multi-disciplinary open access archive for the deposit and dissemination of scientific research documents, whether they are published or not. The documents may come from teaching and research institutions in France or abroad, or from public or private research centers.
L'archive ouverte pluridisciplinaire HAL, est destinée au dépôt et à la diffusion de documents scientifiques de niveau recherche, publiés ou non, émanant des établissements d'enseignement et de recherche français ou étrangers, des laboratoires publics ou privés. 


\section{Reconstructing the globalisation of tourism: A geo-historical perspective}

Andreea Antonescu \& Mathis Stock, Centre de Recherche Interdisciplinaire sur le Tourisme (CRIT), IUKB, Sion, Switzerland

\section{Introduction}

Tourism is a phenomenon that - from a geographical perspective - expresses tensions and contradictions between established places such as central cities, and marginal places such as mountains, seaside resorts or the countryside. It is one the one hand spatially congruent with the nation state's emergence and its attempt to control territories and to domesticate a wild nature interpreted as risky. On the other hand, tourism is contradictory to established spatial patterns by the emergence of geographical locations whose qualities and signification are radically different to previously known spatial forms and whose geographical position make them peripheral. The transfer of "urbanness" is ever-present, and peripherality is coded as a relevant "desire" or a positive value.

Since the beginning of the 19th century, tourism's spatial patterns have changed radically: from a system comprising a small number of places to a global system of tourist places. This globalisation of tourism goes hand in hand with different forms of tourism or "tourist systems" that historians began to describe as "industrial tourism" (Tissot), the emergence of modern tourism around 1830 (Spode) or "mass tourism" since the 1920s (Keitz). It is interesting to note that these periodisations are different and thoroughly embedded in national tourism narratives, since each historian is concerned with his or her own country. Geographers have also proposed a periodisation of tourism systems, dating the emergence of a first tourism system to between 1780 and 1830, a second "industrial tourism system" functioning from the 1870 s on, the emergence of a mass tourism from the 1920s and since (especially in the U.S., the UK and Germany) and the 
current form of tourism can be defined as a "mass, diverse and globalized" system from the 1970s on (Equipe MIT, 2005 ${ }^{1}, 2011^{2}$ ).

This raises the question of globalisation of tourism as a double process of the "touristification" of the world through the application of the tourist gaze to virtually every object and place, and of the emergence of tourism system on a global scale. From a geo-historical perspective, the issue is given by the modality of spatial and temporal dimensions of tourism globalisation. Which spatial patterns of tourist places emerge and how does a "global tourism field" change the value and position of tourist places in relationship to the others? This is one of the major issues raised by tourism globalisation, because the emergence of a global scale corresponds to a change in the competition between the different destinations. It involves the question how tourism, tourist practices and tourist space producers have contributed, for 200 years now, to globalisation and how economical, political and social globalisations have influenced the structure of tourism.

Yet, there is a problem of data. No estimation exists of the number of tourist places in each period of time. Unlike research on the world's process of urbanisation, which is now relatively well documented by historians and geographers (Bairoch, Moriconi-Ebrard), research on the world's touristification is not yet accompanied by quantifications about the number of tourist places in general or related to the types of places. We have no idea about the number of tourist places that emerged in the different periods on a global scale. Only partial analyses allow for an understanding of the quantity of tourist places created, such as Walton's (1983) analysis of the seaside resorts in Great Britain or Spode's (2003) contribution to the National Atlas of Germany. To understand globalisation through densification, concentration and increased dispersion has been a difficult task. To date only one attempt has been undertaken to provide a geo-history of tourism on a global scale: Equipe MIT (2011) collected approximately 2,000 places in order to understand how, at different periods, tourism places are created on a global scale ${ }^{3}$. Their attempt aims, among others, at overcoming a Eurocentric perspective by giving value to the non-

\footnotetext{
${ }^{1}$ EQUIPE MIT (2005). Tourismes 2. Moments de lieux. Paris : Belin. 348 p.

${ }^{2}$ EQUIPE MIT (2011). Tourismes 3. La révolution durable. Paris : Belin. 332 p.

3 See also STOCK Mathis (2008). Il mondo è mobile. In LEVY Jacques (dir.) (2008). L'invention du Monde, Paris: Presses de Sciences Po, pp. 133-158 as explanation for the sources of this database, and Knafou et al. (2012) for an interactive cartography.
} 
European world. Yet, it is impossible to draw on quantitative information from their work, owing to the focus only on the production and not on the collapse of destinations.

The globalisation of tourism therefore raises serious methodological and theoretical problems due to the lack of data needed to understand this phenomenon. We attempt to construct solid historical sources to trace the development of tourism for 200 years and to obtain a cartographic view of the phenomenon. In this article, we propose a methodology in order to construct a data set on the globalisation of tourism. To achieve this, we rely on tourist guidebooks published since 1800 , which are exploited from the perspective of the mentioned tourist places. It is a geohistorical approach insofar as the chosen entry concerns tourist places for which a date is necessary in order to understand the globalisation of tourism.

\section{Asking methodological questions}

How does one implement the reconstruction of tourism globalisation and how can the current globality of tourism be understood? Which data collection methods should we implement? How should we use this data? Which sources do we use? To answer these questions, we have built a methodology in order to construct the necessary empirical data to reconstruct one aspect of the globalisation of tourism.

\subsection{Methodological aims}

Which kind of information is to be produced about the tourist places? Two elements seem crucial. First, the emergence of specific places as tourist places seems particularly interesting in order to say something meaningful about the production of tourist places, which has been constantly renewed since 1750 . Second, the different modalities of tourism over a longue durée would allow a distinction between the reproduction of tourism in places already qualified as tourist places and tourism's temporary or permanent failure in tourist places. This implies 
"following" a tourist place from its tourist emergence to the present. From a methodological perspective, the following questions need to be addressed:

1. Which is the moment of emergence of tourism?

1.1. To establish the specific moments of emergence for tourist places that were considered touristic for the period 1800 to 2000 .

1.2. To identify and quantify tourist places produced between 1800 and 2000 .

2. How does tourism change over time in tourist places?

2.1. To identify the moment of failure of various places' tourist function and quantify the number of tourist places that ceased to be touristic.

2.2. To identify and quantify the places that managed to maintain their tourism function during the considered time-frame.

2.3. To identify and quantify places where tourism has been intermittent, i.e. places that recovered a temporarily lost tourist function.

3. Which quality of tourist places?

3.1. Identify places where specific tourist practice(s) took place, such as seaside or winter resorts.

3.2. Determine the types of tourist places, such as sites, resorts or cities ${ }^{4}$.

If these methodological questions are acknowledged, further issues must be considered. What is meant by "moment of emergence" of a tourist place and how can we get sound, robust and comparable information about it? What is meant by temporary and permanent failure of the tourism function and how does one measure them? How does one determine the maintenance of a place's "touristicity" over time? These issues raise problems of both definition and methodology, because different answers to these questions will provide different empirical data. For instance, a tourist place defined by infrastructure, presence of tourists, or tourism's dominance as economic

\footnotetext{
${ }^{4}$ This is a simplistic taxonomy of tourist places based on the work of Equipe MIT (2002) that would necessitate a thorough discussion, which cannot be done here.
} 
activity lead to three different dates of emergence. The information about the "first tourist", "first tourist infrastructure" or economic activity is embedded in various mythical and statistical narratives, which define the moments of emergence in different ways. Furthermore, there is a need for a coherent, global source on tourist places for the last 200 years.

Several solutions are possible. Here, we make the choice to rely on guidebooks and therefore define the emergence, maintenance and failure of tourism as the moments when the guidebook constructs them as tourist places. This means that the guidebooks are the means by which a tourist place is defined, with all the strengths and limitations such a status entails. Especially, it involves the notion of tourist places as knowledge constructions; in this case, the guidebook contains a socially and culturally constructed tourist gaze, resulting in a specific geographical imaginary. As a result, the reconstruction of the globalisation of tourism is a specific selection of tourist places as they appear in guidebooks, thus recognized as such by specific actors with specific interests. The results obtained from this source will then reflect a specific and limited perspective ${ }^{5}$; a reconstruction of a social construction of tourist places. Here, the guidebook is used as a tool for social confirmation of the emergence of a tourist place, because only the mention in the guidebook makes a tourist place a recognized tourist place that can be used in our database. Therefore, the image offered by the guidebooks on the global tourist places is partial and incomplete.

\subsection{Tourist guidebooks as a source}

An analysis of the literary genre "travel guide" as well as a series of methodological tests show that guidebooks are a very rich source ${ }^{6}$. This source is capable of delivering usable information to determine the moment of tourism emergence, the permanent or temporary failure, the maintenance of tourism, and the nature of tourism practices in resorts. Firstly, it is a source that offers information on tourist places and practices both in terms of time (the first guides, from 1780) and spatiality (the world). Secondly, guidebooks ensure the accessibility of comparable

\footnotetext{
${ }^{5}$ At the same time, it helped to promote some tourist places and to remove others. It makes selections; it decides.

${ }^{6}$ See Chabaud et al. (2000) as well as Morlier (2007) for an in-depth analysis of the tourist gaze constructed by guidebooks.
} 
information. Although it is not easy to gain access to the guidebooks, a certain amount of information is ensured and a freedom of choice of corpus is guaranteed. Thirdly, each travel guide offers information on similar areas of interest: practical information (hotels, restaurants, transportation), administrative information, geographical information, etc. Fourthly, there is a similar organisation of the content among different publishers. Lastly, thanks to the genre's longevity, we can follow a place in time or specific information about a place by browsing through several editions. The multitude of editions, collections and places described make guidebooks a robust and consistent source.

\section{Corpus construction: Guidebooks as source}

This begs the question of choice. Which publishers does one choose? How does one select the guidebooks? How does one find them? There are several factors to consider in guidebook selection: a guidebook is published by an editor or publisher, it is reissued at certain time intervals, it is devoted to a specific geographical area, and variants of it are translated into other languages.

\subsection{Publisher selection}

The first goal is to make a selection according to the editor or publisher. We selected only the largest collections of guides: Baedeker, Murray, Guides Joanne, Guides Bleus, Guide du Routard, Fodor's, Lonely Planet (see Figure 1), verifying that all continents are considered. However, for the time prior to the appearance of large collections, we selected among the best known and most published authors, such as Reichard and his successor, Richard. Figure 1 explains our choice of travel guidebook publishers from the genre's appearance. The aim is to compare the different visions. Therefore, different corpi should be comparable in terms of time of publication.

The space described by a travel guide is a very important element. Extensive areas are privileged, because they offer a large number of tourist places: national spaces and associations of national or regional spaces. According to affinities, the description of one specific place promoted in a guidebook can be very different from one publisher to another. To avoid dependence of affinities 
and reference publishers, we propose to consult several publishers, per specific year (or the closest period to it) and for the same space (see Figure 1). In the process, we set aside the local level.

Figure 1: Selection of travel guides

Design and production: A. Antonescu

To meet tourists' needs and to keep up with the changes in time, travel guides information is frequently renewed. These updates may include corrections of errors made in previous editions, additional information on an aspect of the journey (life policy, details of distances, practical new features, new tourist places, etc.). These updates are methodologically exploited here: they can measure, for each update, the difference between the places mentioned in the guides. Thus the increase or decrease in the number of tourist places can be measured.

Typically, an editor publishes a guide in his or her native tongue and can then publish translated versions of the same guide. Translated editions may correspond to a part of the original collection, but may also represent new titles with no counterpart in the editor's native language; this is the case with the German publisher Baedeker, more than with other publishers. We have chosen the editor's language, because it is more likely that we find several guides for more spaces.

\subsection{Constitution of the empirical material}

We consider the guidebooks as lists of tourist places. The method is to extract the tourist places that appear in a travel guide, and the guide's date of publication. We begin with the first guide issued and follow with the various published editions. The first places mentioned in the first guides are considered as the first tourist places, and their moment of tourism emergence as the date of the first edition to include them. As we progress, we discover new tourist places that appear or tourist places that are no longer considered as tourist places by guidebook publishers. 
Our proposal is to record the places found in the alphabetical index guides. The alphabetical index is a directory of all the places mentioned in a guide ${ }^{7}$. The locations of the alphabetical index are then entered into a database. This has the following implications:

- The moment of tourism emergence adopted corresponds to the first mention of a particular place in a travel guide ${ }^{8}$.

- A tourist place's moment of failure is when a place appears for the last time in all guidebook series. Accordingly, we note the year of the edition to mention a specific place for the last time.

- "Permanent" places, i.e. places that maintain their tourist function, will be subject to verification of their presence in the guidebooks from their time of emergence as tourist places to the present. We must therefore find the same place name in each edition available between these dates ${ }^{9}$.

In short, this is to ensure that we note all the places mentioned in a guidebook while checking for updates of places in the following and earlier editions - as appropriate. This implies to follow a collection of guides for a chosen space over time.

\section{Data analysis}

We will analyse once data collection is completed. We will create databases and then process them.

\subsection{Constructing tourist place emergence, intermittence and failure}

\footnotetext{
7 It must be noted that, in our view, all the places mentioned in a guidebook are tourist places. While one can argue this choice, it allowed us to have a consistent source of what a guidebook considers a tourist place at one point in time.

8 This is a second limitation: it is the guide that counts, not the date when the first tourist arrived in the place. Again, the coherence of the source that governs the choice.

9 Regarding the collection of tourist places, we will use a method of computer input, alternating with manual data entry.
} 
On this basis, we will indicate each year of publication we have chosen for a specific space in a column (see Table 1).

Table1: Example of the guidebook on Winter Mediterranean resorts between two editions (partial extraction of the original table)

\begin{tabular}{|c|c|c|c|c|}
\hline 1883 & 1898 & New places & $\begin{array}{l}\text { Tourist } \\
\text { failure }\end{array}$ & $\begin{array}{l}\text { Tourist } \\
\text { maintenance }\end{array}$ \\
\hline Ajaccio & Agay & Agay & & Ajaccio \\
\hline Alassio & Ajaccio & & Alassio & \\
\hline Albenga & Antibes & & Albenga & \\
\hline Antibes & Bandol & Bandol & & Antibes \\
\hline Arenzano & Beaulieu & & Arenzano & \\
\hline Beaulieu & Bordighera & & & Beaulieu \\
\hline Berthemont & Bormes & & Berthemont & \\
\hline Bollène & Cagnes & Cagnes & Bollène & \\
\hline Bordighera & Cannes & & & Bordighera \\
\hline Bormes & Cannet Le & Cannet Le & & Bormes \\
\hline Cannes & Cap d'Antibes & Cap d'Antibes & & Cannes \\
\hline Cogolin & Carqueiranne & Carqueiranne & & Cogolin \\
\hline Dolce Aqua & Cavalaire & Cavalaire & & Dolce Aqua \\
\hline
\end{tabular}

operation consists in comparing two lists of tourist places, each representing one year's edition. The first step is to establish the moment of a tourist place's emergence. Through conditional formulas, we extract the locations mentioned in one edition but not in the previous edition. For example, Table 2 includes two years of Joanne guides on winter resorts of the Mediterranean, 1883 and 1898. In order to know which new places appeared in 1898 and were not mentioned in the previous edition, of 1883, we obtain the places listed in the column 1898 and are not found in the 1883 column. The year of publication represents for these new places the moment of their tourism emergence. Next, in order to establish the place names that have ceased to be tourist places between the two dates analysed, we obtain the places listed in the column 1883 and not found in the 1898 column ("tourist failure"). The method is the same as for the moment of 
emergence, except that the column order in the formula is reversed. This seeks to establish which places were tourist places until 1883, but no longer appear in the next edition, of 1898. A third process is to establish the places that have continued to be promoted in guidebooks, which corresponds to places that appear in both columns ("permanent places".

These processes are repeated for every edition until the last edition mentioned in the database for one specific guidebook. In this way, we obtain relatively reliable dates for each place. This information is then used to quantify the number of newly produced tourist places, the number of places that have lost their tourist function, and the number of tourist places to maintain their tourist function.

\subsection{Mapping tourism globalisation}

The purpose of maps is to represent geographical phenomena whose spatial configuration produces meaning. Maps can be defined as "representations characterized by the construction of an analogous image of a space"10 (Lévy and Lussault, 2003, pp. 128). A map seeks to make visible "the interactions between space and extension, the relation between a particular spatiality and a basemap" (Lévy and Lussault, 2003, p. 131).

To illustrate the problem of a geo-historical approach to tourism globalisation, we propose several maps that allow a glimpse into this methodology's potential. A potential exploitation of the data is by mapping tourist places for different periods ${ }^{11}$. This cartographical approach raises several questions: How do we map tourism globalisation? Do we represent the set of tourist places at a given period or for more precisely defined dates? Which base map would be most suitable to represent it?

Globalisation is defined here as an ongoing process of circulations, material (objects, people) and intangible (ideas, feelings) exchanges between individuals in the spatial arrangement called world. The ongoing integration of places at a global scale and the emergence of spatial

\footnotetext{
10 Translation ours.

${ }^{11}$ Because data collection is ongoing, we are unable to include maps from our database here, but rely on data provided by the Equipe MIT (2011) study.
} 
arrangements of virtually all social realities at a global scale define the process of globalisation ${ }^{12}$. Mapping the continuing emergence of tourist places at a global scale is then one of the possibilities of addressing tourism globalisation. The question that arises is which cartographic form is adequate for representing the globalisation of tourist places. Two elements seem important: First, a global mapping would need to show the world as a whole, without political boundaries at a national scale, without separation between continents, and without the usual "Eurocentrism". Therefore, a global mapping would need several central points. Second, since globalisation is a process, the most suitable form of mapping would be a dynamic one, which can show the flow of tourist places in time. To create this, we can choose between two types of mapping: A sequence of static map at a given time or period, or an animated map presenting the evolution of tourist places in time and space as a moving picture. Since it is unlikely that the second solution can be integrated into a paper, we chose to focus on the former, more traditional solution, and show here the development of tourism ecumene since its emergence to date.

One can map both by periods and by specific dates. The issue lies in the choice, which influences the maps' interpretation. The quantity of these periods or dates also represents a key step. Indeed, for a static map to be easily read, it needs to contain a limited number of graphic and symbolic entities. The following maps are an example of mapping by period. They show the emergence of tourist places in time, from the first tourist places to current tourism places ${ }^{13}$.

\footnotetext{
${ }^{12}$ See Robertson \& Fechtner (1985) for their definition of globalisation as "the processes by which the world is being made into a single place with systemic properties" and Elias (1994) as "ongoing extension of the chains of interdependence”. See also Lévy (2003) and (2008) for interesting conceptual tools with which to understand globalisation, such as the distinction between "globalising" and "globalised" places.

${ }^{13}$ As noted, the data used for this mapping was provided by the Equipe MIT studies.
} 
Figure 2: Tourist places to emerge before 1800

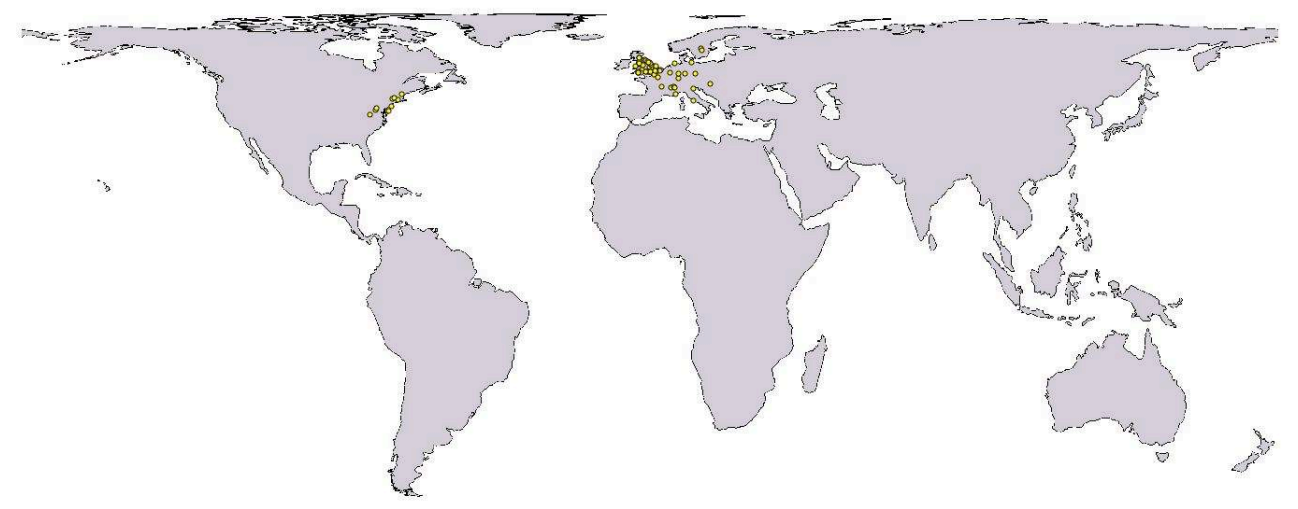

*

Figure 3: Tourist places to emerge between 1800 and 1849

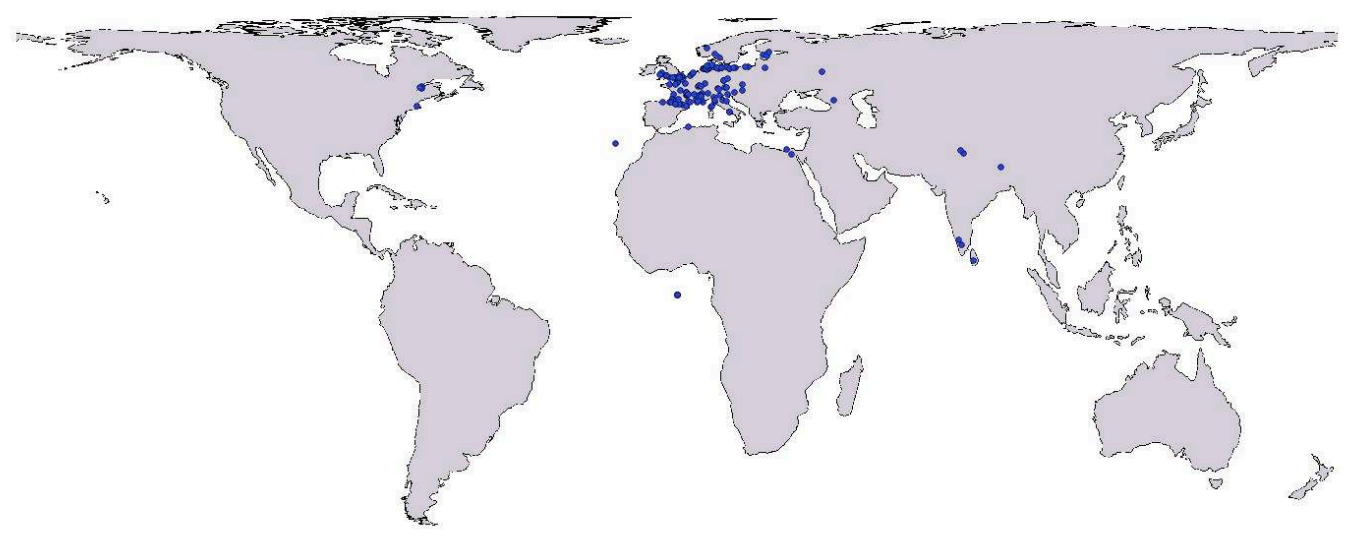

* 
Figure 4: Tourist places to emerge between 1850 and 1899

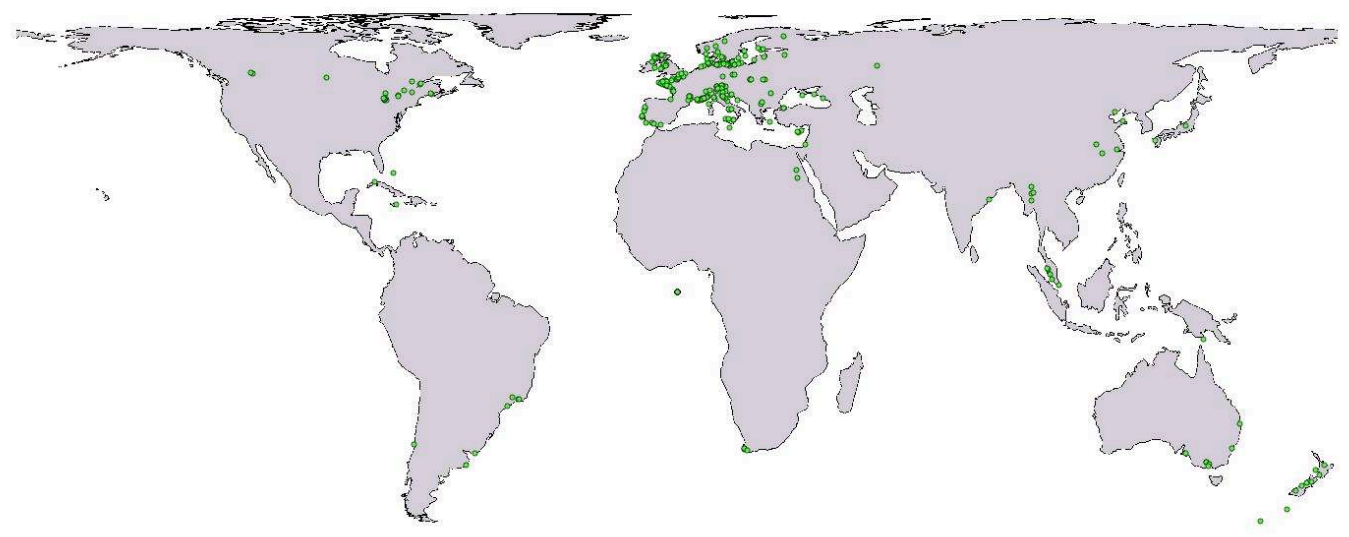

*

Figure 5: Tourist places to emerge between 1900 and 1949 


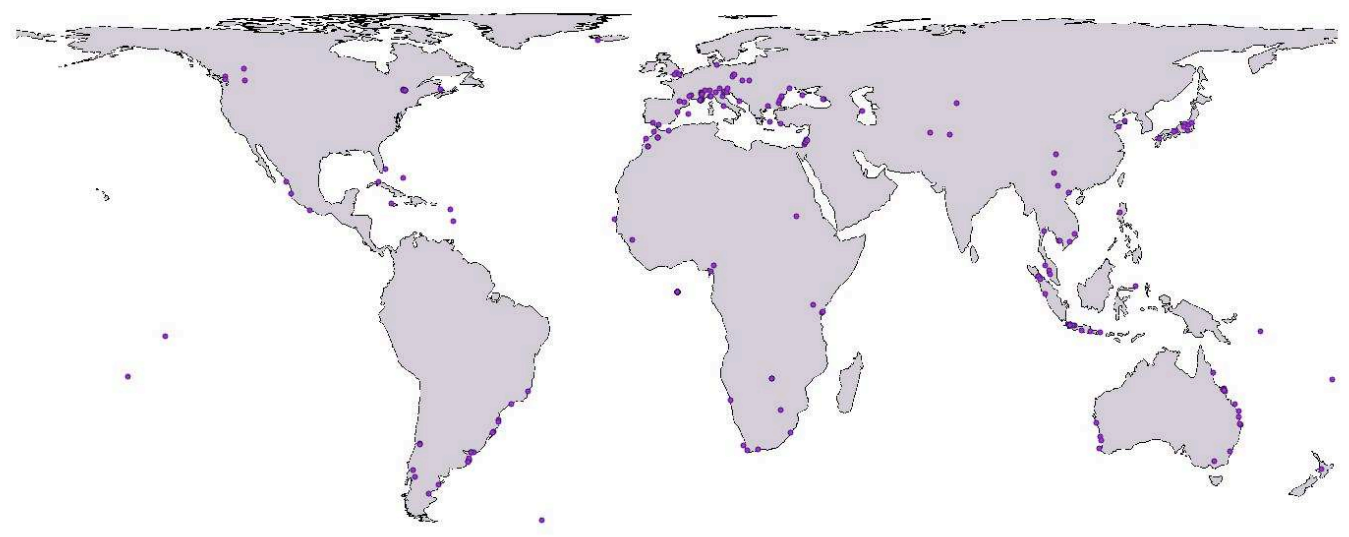

*

Figure 6: Tourist places to emerge between 1950 to the present
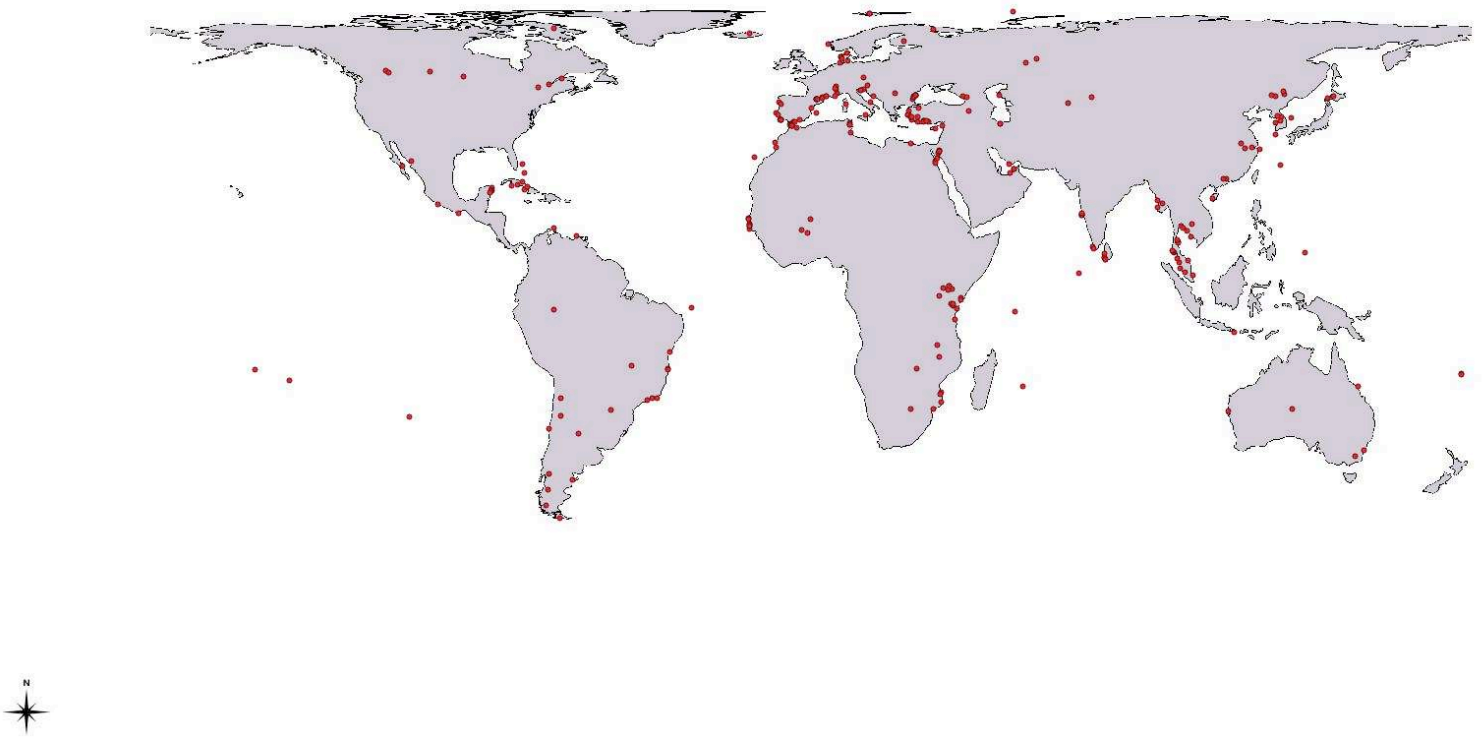

However, the choice of base map is crucial when globally mapping tourism, because very different spatial forms of the continents are possible when projecting the three-dimensional earth 
on a two-dimensional sheet of paper. Cartography has been developing a great number of different base maps of the earth that depend on different projections. The choice among these base maps is therefore crucial because, depending on the map projection, one can show the same spatial referent - i.e. the world - in different forms ${ }^{14}$. To address this problem, we show two different cartographic forms created from different base maps.

Figure 7: Tourist places and their moment of emergence by period

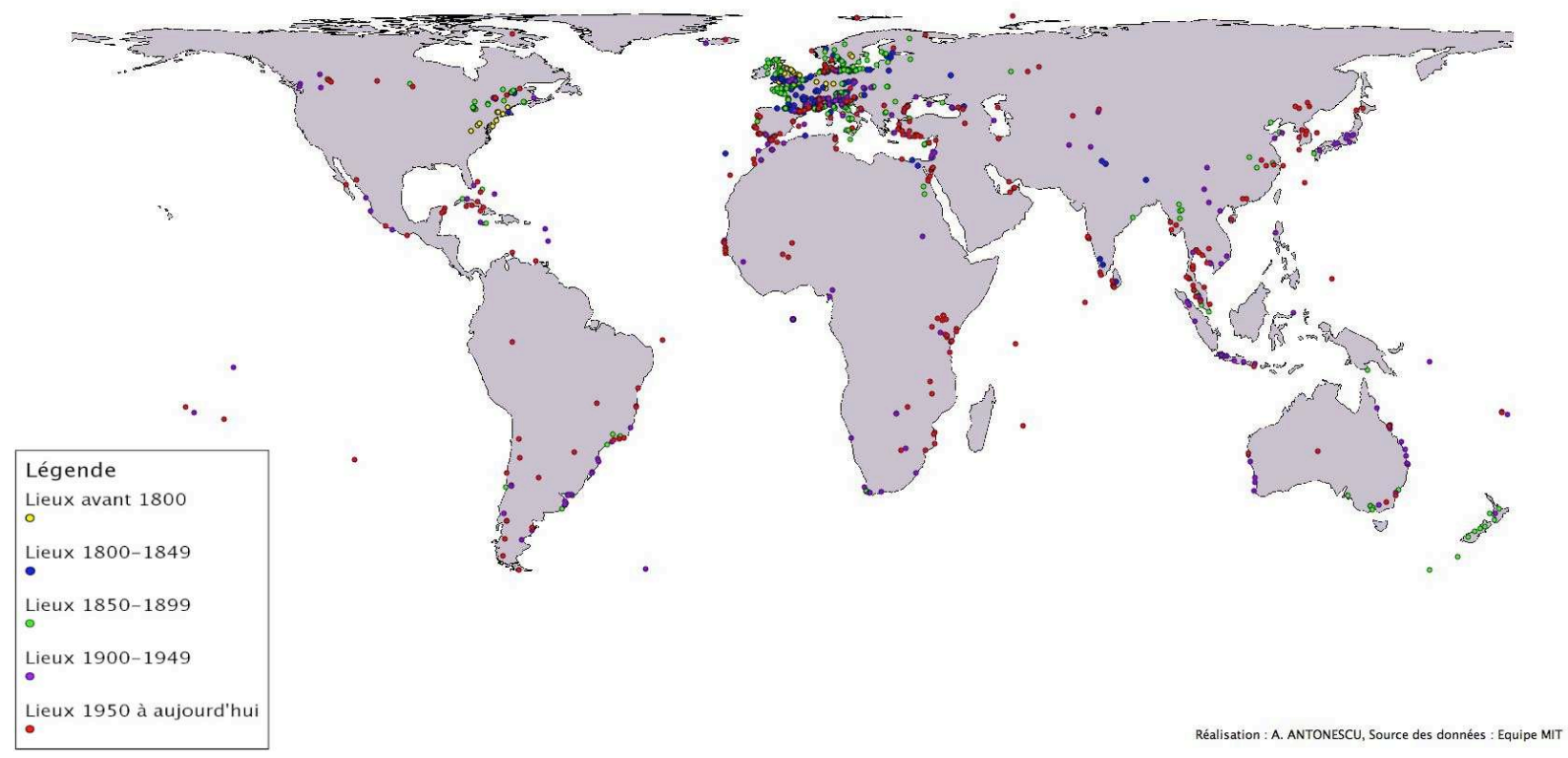

Design and production: A. Antonescu; source data: Equipe MIT

This first map (Figure 7) shows tourist place distribution in time and space. Specifically, it shows the moment of emergence of tourist places and it represents the sum of the five previous maps. To observe the increasing tourism place density over time, we chose five periods: before 1800, $1800-1849,1850-1899,1900-1950$, and 1950 to the present. For each period, we notice the appearance of new tourist places.

\footnotetext{
${ }^{14}$ See Woodward on this question of different projections.
} 
This map (Figure 7) was created from an equal equidistant projection. One of the problems that this projection raises is that it cannot cover the poles; it is incomplete. Another is that it is centred on the Atlantic, and with a focus on the south. It is similar to the Mercator projection, which, until recently, was considered the classical projection and used as such. However, depending on the phenomenon or the geographical information, one can choose a different projection. Thus, we created the following map.

Figure 8: The system of tourist resorts in 2000

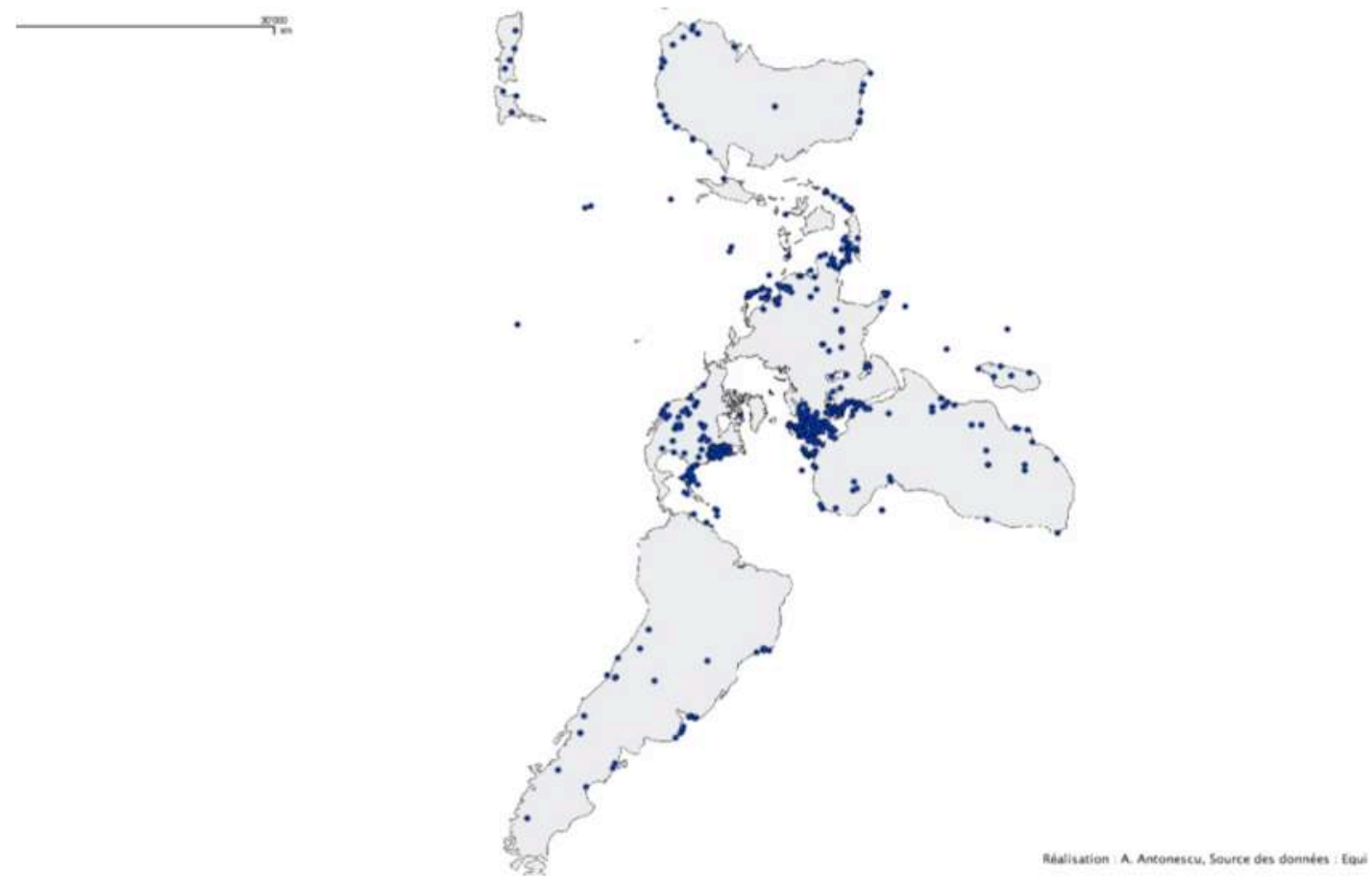

Design and production: A. Antonescu; source data: Equipe MIT

The second map (Figure 8) shows the spatial extension of resorts, combining all practices, throughout the world. For this map, we chose a North polar stereographic projection, because it allows one to see the world as a unique island in a single ocean, as it were. There is no separation by oceans or by cardinal points. 
This discussion of mapping methodology shows the difficulty of mapping tourism globalisation as well as possible solutions. It allows for constructive dialogue between historical and geographical problems.

\section{Proposing explanatory schemes}

How does one conceive the touristification of the earth and the emergence of a global tourism ecumene? Do we dispose of theoretical elements so as to propose consistent, coherent descriptions and explanations of the phenomenon? The literature focuses either on the touristification of singular places without reference to globalisation, or on globalisation issues without reference to tourism ${ }^{15}$. Thus there seems to be a need of adequate conceptualisation. Without such conceptual elements, there would also be difficulties in data analysis and in proposing an interpretation of the cartography of tourism globalisation. Here, we propose three conceptual elements for understanding tourism globalisation from a geographical perspective.

\subsection{Circulation models: "Moments de lieux"}

The classical notion of "spatial diffusion" captures the fact that, initially, few places innovated and that over time, more and more places are innovating ${ }^{16}$. The "product life cycle" is thus transposed into the space where the elements are diffused to an ever-increasing population and growing number of places. However, this does not seem sufficient to analyse tourism globalisation. Instead of having a diffusion of identical elements, tourism practice forms and modalities change over time and space. They change over time because, depending on when the practices are adopted, the social contexts change and thus also their significance and

15 The studies on global history. See, for example : MACGILLIVRAY, A. (2006). A brief history of globalization. The untold story of our shrinking planet. London: Robinson. 338 p.; OSTERHAMMEL, J., PETERSSON, N. P. (2005). Globalization. A short History. Princeton: Pricenton University Press. 182 p.; HOPKINS, A. G., (2002). Globalization in world history. London : Pimlico. 278 p.

${ }^{16}$ See the classic studies by E. Rogers in : A. Stewart Fotheringham and Peter A. Rogerson (2009). The Sage handbook of spatial analysis. London: Sage. 511 p. 
signification; they change spatially because, depending on where the practice is adopted, cultural contexts change their significance and signification.

Hence the need to seek alternative explanatory schemes in which notions of the "circulation", hybridization of production and reproduction of tourist places replace the notion of diffusion ${ }^{17}$. A key term could be the "circulation of model places" as an explanation for tourism globalisation. Indeed, Equipe MIT (2005) identified a finite and small number of tourist places that had been established at some point. Called "moments de lieux", these space-time coordinates of tourism practices are supposed to play the emblematic role model for other places regarding their tourism emergence. Indeed, "we assume that all the tourist places we identified (about 30) including Disneyworld, Arcachon, St Moritz, Paris, Yellowstone were used for referencing hotbeds of innovation. We assume, therefore, in consideration of our present knowledge, that there is no spontaneous generation of places. In this way, the tourist dynamic can be summarized as a dissemination of spatial patterns, like a sort of models on which the various actors activate in order to match places and practices" (Equipe MIT, 2011).

The reference to those few models is thus one of the elements with which the database can be analysed. Global tourism expansion is interpreted as owing to the circulation of a number of place models whose emblematic element play the role as reference for other places ${ }^{18}$. The series of inventions of emblematic tourism practices since 1800 are therefore key to observing the emergence of tourist places.

\subsection{Generalisation of the "tourist gaze" on a global scale}

Another explanatory principle is the generalisation of the tourist gaze towards an increasing number of practices, places and objects. "Tourist gaze" is an interesting concept that could help to understand tourism globalisation. In John Urry's (1990, pp.1-2) initial formulation, "tourist" is a different way of looking at the environment than in everyday life, a more detached view: "we look at the environment with interest and curiosity". This gaze is not uniform, but variable: "there

\footnotetext{
${ }^{17}$ See the geographical and anthropological literature on circulation and hybriditization : Equipe MIT $(2011,2005)$,

${ }^{18}$ See Debarbieux's “ haut-lieu” (1995) and Micoud (1991) for the notion of emblematic place.
} 
is no single tourist gaze as such. It varies by society, by social group and by historical period". This is one important indication for a geo-historical analysis of the tourist gaze because "the gaze in any historical period is constructed in relationship to its opposite, to non-tourist forms of social experience and consciousness" ${ }^{\prime 19}$. Therefore, the tourist gaze is constantly changing, because for 200 years, new items are added as "videnda" for tourists. First the ruins of classical antiquity, then the glaciers, high mountains, waterfalls, the beach, the city, the pyramids, the wilderness, safari, Kathmandu, the World Heritage of Humanity list, museums, etc. ${ }^{20}$. Hence the assertion that "anything is potentially an attraction" (p. 192) ${ }^{21}$, because the tourist gaze can be applied to almost any object, transforming it into an "attraction".

The invention of a tourist place by a tourist gaze "subverts" a place's value ${ }^{22}$. Indeed, a beach or a mountain pasture without economic interest and symbolic value suddenly becomes a positively valued place on which to build a hotel. The break with other actors' common sense is one of the characteristics of the tourist gaze in its implementation. It helps one understand how the tourism globalisation takes place, i.e. as ever-new inventions of places and new symbolic values assigned to places. Different places than formerly ones are "inhabited" and thus placed in the global ecumene, and thus participate in tourism globalisation.

As Equipe MIT (2011) $)^{23}$ notes, "the association between practices and places (...) is the mainspring of the tourist ecumene's globalization. This specific practices/places association is derived from a 'tourist gaze' and from an actual and virtual capacity of valorisation of all parts of the world". This global tourist gaze on virtually any element of the cultural, bio-physical, social, tangible or intangible, ideal or material, and symbolic world is one of the powerful elements that leads to the formation of a global tourist ecumene. The tourist gaze combines both inventions of ever-new tourism practices and the circulation of practices already mastered in previous forms of tourism. The extension of the already trained tourist gaze on not-yet-touristic elements and the

\footnotetext{
${ }^{19}$ Although widely cited, there is also criticism of the notion "tourist gaze", especially by MacCannell (2001) and Spode (2004) on the "scopic regime" implied by the definition of the gaze as "looking". We acknowledge this criticism, and see the tourist gaze as "relationship to the world" in a more symbolic dimension, rather than in a mere perceptive dimension.

${ }^{20}$ As noted, the work on the reconstruction of different tourism attractions and practices was done partly by Löfgren (1999), systematically by Equipe MIT (2005). We do not go into detail here about the many tourism practices inventions.

${ }^{21}$ MACCANNELL Dean (1976). The Tourist: A New Theory of the Leisure Class. New York: Schocken Books.

${ }^{22}$ KNAFOU Rémy (1992). L'invention du tourisme. In Bailly, Ferras, Pumain (ed.) (1992). Encyclopédie de la géographie, p. 851-864.

${ }^{23}$ EQUIPE MIT (2011). Tourismes 3. La révolution durable. Paris : Belin. 332 p.
} 
invention of new tourist gazes could be read through the spatial extension of the tourist places in a given period.

\subsection{The emergence of a global tourism field}

One can understand tourism globalisation not only as a circulation problem, but also as the emergence of a set of places and locations and interdependent actors on a global scale. Tourism is structured on a global scale at which competition, cooperation, regulatory actions, circulation of images etc., are carried out. If one approaches the globalisation of tourism as an emerging global configuration, the issue of proper conceptualization can be raised ${ }^{24}$. The notion of the emergence of a "global tourist field" could be useful for analysing the interdependencies of tourist places on a global scale (Clivaz, Nahrath \& Stock, 2011) ${ }^{25}$.

"The tourism capital of a resort is 'brought into play' (ie more or less strategically mobilized) by the actors of the 'local' tourism system (within the meaning of localized) in order to advantageously place the resort on the national and international tourism market (worldwide), that is to say also in the context of a configuration (World) composed of all the actors / agents (individuals, groups, businesses, public and private organizations), institutions (codes, charters and other regulations applicable international, national and regional) and places (resorts, cities, sites, etc.) specifically concerned with the interests related to tourism in its many dimensions considered economic, political, social, environmental, legal, individual etc. We call 'tourist field' this configuration in which recognition of specific interests allows actors of tourist resorts to mobilize and 'play' their 'tourist capital' in order to place themselves with their competitive advantages in this game both a commercial and a non-profit one" ${ }^{\text {"26. }}$.

Tourist resorts develop a tourist capital, which they engage in the global tourism field. This is an

\footnotetext{
${ }^{24}$ Several terms might be useful to frame the phenomenon: field, system, network and configuration are in use in different theoretical and disciplinary contexts. In sociology, "field" and "configuration" are used to describe social interdependencies, for example in Robertson's "global religious field"; in geography, they are used for a spatial system and a network of places, for example, as "global cities network" (Taylor, 2004).

${ }^{25}$ CLIVAZ Christophe, NAHRATH Stéphane, STOCK Mathis (2011). Le développement des stations touristiques dans le champ touristique mondial. Mondes du tourisme (hors série "Mondialisation et tourisme", dir. Duhamel Ph. \& Kadri B.).

${ }^{26}$ Translated by us.
} 
attempt to understand the global competition and has effects on the operation of tourist places. This global field can be understood from a geographical perspective as a network of tourist places as well as networks of multiple actors whose spatial relationships such as distance, limits, location and geographic imaginations are key. The global tourism field's spatial dimension could be approached by a set of tourist places whose interdependencies are formed by relationships of competition and cooperation. For example, European ski resorts are no longer competing only among themselves, but also compete in relation to new places that tourists practice in boreal winter, such as tropical destinations. This framework allows one to reconstruct the globalisation and emergence of a global tourist field characterised by densification and differentiation.

Secondly, tourist places have unequal tourism intensities, unequal reputations or "spatial distinctions" 27 . What has emerged is a global hierarchy of tourist places depending on their images, symbolic capitals or attendance. One way to operationalise the notion of a global tourism field from a geographical perspective would be by dealing with a global network of tourist places that is different for each historical period. The globalisation process could be read through the number and quality of tourist places. It could also be read through the changing globalisation of a tourist place over time. These would be tourist places with global influence and whose attendance puts them among the most important. Interesting examples are Zermatt or Bali, whose current global attendance is evident; however, they were touristically unknown in 1800, when Brighton and Chamonix were the emblematic tourist places.

A global network of places emerges with specific spatial patterns, highly differentiated between emblematic places and ordinary tourist places, between different tourist place qualities (sites, resorts, cities), and between functions for discovery, relaxing, playing, shopping, etc. "The tourist centers worldwide, whether they are cities with tourist functions (Paris, London, New York, etc.), touristified cities (Venice, Bruges, etc.), natural curiosities (Iguaçu Falls, Kruger Park, Ayers Rock, etc.) or cultural curiosities (Machu Picchu, Angkor Vat, etc.), are the vertices of a complex network whose segments are traversed by mostly international tourists in search of discovery. This network is superimposed on a range of tourist areas of very diverse size and nature given by tourist conurbations, suburban areas of recreation and tourism, etc. (...), which were developed

27 CHADEFAUD Michel (1988). Aux origines du tourisme dans les pays de l'Adour. Du mythe à l'espace : un essai de géographie historique. Pau : Cahiers de l’Université, no. Spécial. 
for relaxing and playing destined for regional or national clientele" (Equipe MIT, 2011). This description of the essential spatialities of tourism is interesting, because it allows for thinking in terms of networks of tourist places, consisting of cities but also of sites. This puts one on the track to design this "global tourist space" as an arrangement of cities, sites, resorts and counters connected by the circulation of images, tourists and capital, all hierarchically ordered through symbolic capital. This is how a global hierarchy of resorts, spots, cities, sites and parks is built and how globalisation as a process can be understood by rebuilding the densifications and the successive hierarchies of the tourism ecumene. One of the crucial elements of tourism development lies in the question of changing competition between tourist places. The reconstruction of the "tourist field" for each period between 1800 and 2000 seems to be one way to better understand how globalisation is a key problem for various tourist places.

\section{Conclusion}

The methodological and conceptual elements developed in this article are meant to be milestones in our quest to develop a more precise understanding of tourism globalisation over the past 200 years. There is a lack of quantitative and qualitative information, partially because "methodological nationalism" constrains historians and geographers to their "home" country without addressing the wider context. The movement of "global history" seeks to go beyond this classical limitation and studies globalisation, but has not yet discovered tourism as a central problem of inquiry. Our geo-historical approach allows a specific communication between two scientific disciplines: history and geography. Their combined analytical techniques can be helpful in constructing tourism globalisation as a major research problem.

The geo-historical approach we have chosen focuses on the emerging system of tourist places on a global scale. The methodological solution focuses on the guidebooks constructed as a source for information on tourist places' dates of emergence and failures as well as on the quality of tourist places. Furthermore, it proposes a cartographic form of knowledge that allows one to grasp more adequately tourism globalisation's spatial dimensions. This methodological protocol is an ambitious scheme to follow, the first of its kind in research on the globalisation of tourism. It is a complex proposal which has limits, but can simultaneously be reproduced or supplemented by 
other researchers in future research on the same type of subject. It was also designed in order to think of new ways to construct, process and analyse empirical data.

A more thorough understanding of the ongoing globalisation process means developing both methodological and conceptual tools. We proposed three interpretive elements with which to analyse the data set. First, a circulation of place models as reference for other places could explain why, at some point, similar infrastructure and practices shaped tourist resorts and cities. Second, the generalisation of the tourist gaze could explain the impressive densification of tourist attractions during the past 200 years. Third, the emergence of a global tourist field can help to grasp the hierarchies of and differences between the global set of tourist places as well as the phenomenon's global scale.

Finally, this study represents the first step towards understanding tourism globalisation. It can unearth further explanations about the worldwide network of tourist places, its spreading configuration in time and space, and its role in the globalisation process. Naturally, our research focuses only on the spatio-temporal coordinates of tourist places. But, the expectation is that, in future research, our findings will be complemented with other indicators (such as the ratio of tourists to locals in each tourist place, the number of tourist nights, the presence of a hosting infrastructure, etc.), which can measure the changing touristicity and quality of tourist places. 